\title{
Nuclear terrorism in Africa: the ANC's Operation Mac and the attack on the Koeberg Nuclear Power Station in South Africa
}

\author{
Jo-Ansie van Wyk $\boldsymbol{K}^{*}$
}

\begin{abstract}
In December 1982, four explosions occurred at Africa's only nuclear power plant, Koeberg. Situated north of Cape Town, a fully on-steam Koeberg could have spread radioactive material over a very large populated area. The banned, and apartheiddesignated terrorist organisation, the African National Congress (ANC), regarded by the South African government as a Muscovite client, accepted responsibility for the attack which was designed to hit at the heart of white South Africa and its security apparatus. While the ANC won the propaganda war in this instance, the South African government suffered a humiliating political and economic blow. This article shows that the Koeberg attack took place during a new phase in the ANC's liberation struggle, a phase which used small operational units to, inter alia, target state-owned energy facilities. The attack on Koeberg is also indicative of the ANC's opposition to the development and maintenance of a nuclear weapons programme and nuclear weapons in South Africa at a time when the country was being increasingly isolated on account of its suspected nuclear weapons programme.
\end{abstract}

Keywords: South Africa; ANC; armed struggle; Umkhonto we Sizwe; Koeberg Nuclear Power Station; nuclear terrorism; Rodney Wilkinson; Aboobaker Ismail; Africa Hinterland; Dolphin Unit; Operation Mac.

\section{Opsomming}

Vier ontploffings het in Desember 1982 by die enigste kernkragstasie in Afrika, die Koebergkernkragstasie, plaasgevind. Indien die kernkragstasie operasioneel was, sou die radioaktiewe materiaal daarvan 'n groot bevolkte gebied rondom Kaapstad affekteer. The verbanne en verklaarde terroriste organisasie, die African National Congress (ANC), 'n Moskou-kliënt, het verantwoordelikheid aanvaar vir die aanval, wat ten doel was om die veiligheid van blanke Suid-Afrika te bedreig. Die ANC het die propagandastryd in hierdie geval gewen en het die Suid-Afrikaanse regering 'n vernederende politieke en ekonomiese nekslag toegedien. Die artikel dui aan dat die

* Jo-Ansie van Wyk is a member of the University of South Africa's Department of Political Sciences.

How to cite this article:

J. van Wyk, "Nuclear terrorism in Africa: the ANC's Operation Mac and the attack on the Koeberg Nuclear Power Station in South Africa", Historia 60, 2, November 2015, pp 51-67. http://dx.doi.org/10.17159/2309-8392/2015/v60n2a3

Copyright:

(C) 2015. The Author(s). Published under a Creative Commons Attribution License. 
aanval op Koeberg deel was van 'n nuwe fase in die ANC se bevrydingstryd teen apartheid - 'n fase waarin die organisasie met behulp van kleiner operasionele eenhede hoofsaaklik staatsbeheerde energie-installasies aangeval het. Die aanval op Koeberg dien as 'n voorbeeld van die ANC se opposie teen die land se ontwikkeling en instandhouding van 'n kernwapenprogram en kernwapens tydens Suid-Afrika se internasionale afsondering en vermoede van die kernwapenprogram.

Sleutelwoorde: Suid-Afrika; ANC; gewapende stryd; Umkhonto we Sizwe; Koebergkernkragstentrale; kernterrorisme; Rodney Wilkinson; Aboobaker Ismail; Africa Hinterland; Dolphin Unit; Operation Mac.

\section{Introduction}

Following a visit in 1978 to communist leaders in Vietnam, the leaders of the African National Congress (ANC), the banned South African black liberation movement and designated terrorist organisation, made significant changes to its approach towards the white minority National Party (NP) government in South Africa. This is, for example, evident in the release of the ANC's Politico-Military Commission Report (the so-called Green Book). ${ }^{1}$ The objective of the new phase was to weaken "the enemy's grip on his reins of political, economic, social and military power, by a combination of political and military action". ${ }^{2}$ This new emphasis was seen in the escalation of acts of sabotage from 1979 until 1982. These incidents increased from 12 in 1979, to 19 in 1980, and to 25 in 1981. ${ }^{3}$ Targets included police stations; fuel storage facilities at the state-owned oil-from-coal company, Sasol (1980 and 1983); electric power stations; railroads; the Voortrekkerhoogte Army Headquarters (1981); and the Koeberg Nuclear Power Station (hereafter Koeberg) in December 1982. In the wake of these attacks, Oliver Tambo, the exiled president of the ANC, stated that these attacks "combine to demarcate a new level in the armed conflict between the fascist regime and the popular masses, led by the ANC and its allies". 4

One of the most spectacular acts of sabotage against the NP government occurred on 18 December 1982 when four Soviet-made limpet mines exploded at the coming-on-stream Koeberg facility, located north of Cape Town, South Africa. The

\footnotetext{
${ }^{1}$ African National Congress (hereafter ANC), The ANC's Second Submission to the TRC: Umkhonto we Sizwe Operations Report, undated, available at http://www. anc.org.za/show.php?id=2647 (accessed 25 March 2013); K. O’Brien, “A Blunted Spear: The Failure of the African National Congress/South African Communist Party Revolutionary Strategy 1961-1990", Small Wars \& Insurgencies, 14, 2, 2003, p 44.

2 ANC, The ANC's Second Submission to the TRC.

${ }^{3}$ J. Barber and J. Barratt, South Africa's Foreign Policy: The Search for Status and Security 1945-1988 (Southern Book Publishers, Johannesburg, 1990), p 291.

${ }^{4}$ O. Tambo, Opening Speech at the First Conference of the ANC, Department of Information and Publicity, Lusaka, Zambia, 5 July 1983), available at http://www. anc.org.za/show.php?id=4425\&t=ES (accessed 25 March 2013).
} 
armed wing of the ANC, Umkhonto we Sizwe (Spear of the Nation, or MK) accepted responsibility for the explosion. This attack on Africa's only nuclear power station proved to be the continent's only incident of nuclear terrorism, and was a major propaganda victory for the liberation movements that were fighting against the white minority government in South Africa. In addition, at the time the cost of the damage was estimated at ZAR 450-500 million and the commissioning of the plant was delayed by 18 months, adding additional pressure on an already isolated and vulnerable government caught up in the regional and international dynamics of the Cold War. ${ }^{5}$

The purpose of this article is to address a neglected and under-researched issue of South Africa's nuclear past, i.e. the bombing of its nuclear facility. The period covered by this study is from 1978 until 1982, although for contextual purposes some references will be made to events prior to and after this period. These dates coincide closely with the period 1976 to 1984 that has been referred to as the third phase of the ANC's armed struggle. Characterised by attacks on strategic civilian and military targets, this phase culminated in a strategy of "armed propaganda". ${ }^{6}$ The article begins by providing the Cold War context to the events leading up to the bombing of Koeberg. It outlines the state of South Africa's nuclear capability and then proceeds to discuss changes in respect to the ANC's approach to the South African government in the late 1970s. Although the South African government was severely isolated the time as a result of internal and international pressure, the ANC enjoyed considerable international relations with, for example, sympathetic governments in the Soviet bloc and other communist governments such as Cuba and Vietnam. These states offered military training, military bases and other services to the ANC. These services included Moscow's verification of the stolen Koeberg building plans, which paved the way for the planning of the attack. The article then turns to the reaction to the attack and the impact of the bombing. Before concluding the article, two further issues related to the Koeberg incident are discussed.

\section{The nuclear "laager"}

Although South Africa's nuclear past is documented elsewhere, a brief reference to some of its aspects are repeated here in order to contextualise the Koeberg attack. By the mid-1970s, the South African government had already retreated into a "laager" (an enclosure, a place of safety or isolation) due to international isolation and its perception of a pro-communist threat against the country. According to Waldo Stumpf, the chief executive officer (CEO) of the Atomic Energy Corporation (AEC), this was exacerbated by Portugal's withdrawal from its colonies in southern Africa (Angola and Mozambique) and the "uncertainties about the true intentions of the Warsaw Pact countries and especially by the Soviet Union, in the light of their openly

${ }_{5}^{5}$ Truth and Reconciliation Commission (hereafter TRC), Koeberg Power Station Amnesty Decision, 31 May 1999, available online at http://www. justice.gov.za/trc/media/pr/1999/p990531b.htm (accessed 25 March 2013).

${ }^{6}$ O’Brien, "A Blunted Spear", p 29. 
declared expansionist policies in Southern Africa". ${ }^{7}$ This soon converted to a nuclear "laager" with the transformation of the country's nuclear energy programme into a nuclear weapons programme and a nuclear deterrent strategy, approved in April 1978 by the then prime minister, John Vorster. Based on three phases, this new strategy involved strategic uncertainty (Phase 1) during which South Africa's nuclear deterrent capability would not be acknowledged or denied. However, if South African territory was threatened by members of the Warsaw Pact or Cuban forces in Angola, covert acknowledgement (Phase 2) to certain international powers such as the United States would be contemplated; and should this partial disclosure of South Africa's nuclear capability not bring international intervention to remove the threat, the public acknowledgement or demonstration (Phase 3) by an underground test of the country's capability would be considered. ${ }^{8}$

The former defence minister, P.W. Botha, succeeded Vorster as prime minister and introduced the Total Onslaught strategy to counter the perceived international and national threats against the white minority government. Botha centralised state power in the State Security Council, led by Botha and the minister of defence. Against the background of this threat perception, South Africa's first nuclear device was completed in 1978 and the first aircraft-deliverable vehicle completed in 1982. Eventually, six nuclear devices were produced. ${ }^{9}$

State security was not the only objective of the South African government. Another objective was to remain autonomous and self-sufficient because of its international isolation. This resulted in the establishment of a large militaryindustrial complex as well as the development of other heavy industries, all of which required energy to function. Furthermore, the ANC attacks on energy-related facilities impacted on the government's energy vulnerability, an issue which the isolated South African government continuously underplayed because it already faced severe oil embargoes. These developments made the generation of nuclear power all the more attractive. ${ }^{10}$

\section{Origins of Koeberg}

By the mid-1950s, the government realised that in addition to using South Africa's abundant coal reserves, power could also be generated from the country's large uranium deposits. In order to determine the feasibility of the introduction of nuclear

\footnotetext{
${ }^{7}$ W. Stumpf, "Birth and Death of the South African Nuclear Weapons Programme", Paper presented at the 50 years after Hiroshima conference of the USPID (Unione Scienziati per Disarmo), Castiglioncello, Italy, 28 September to 2 October 1995, available at http://www.fas.org/nuke/guide/rsa/nuke/stumpf.htm (accessed 19 April 2012).

${ }^{8}$ Stumpf, "Birth and Death of the South African Nuclear Weapons Programme".

${ }^{9}$ F.W. de Klerk, "Matters Relating to the Nuclear Non-proliferation Treaty, Violence, Negotiation, and the Death Penalty", Statement by the State President to a Joint Sitting of Parliament, Hansard, 24 March 1993, columns 3465-3478.

${ }^{10}$ B. Munslow and P. O'Keefe, "Energy and the Southern African Regional Confrontation", Third World Quarterly, 6, 1, 1984, pp 25-42.
} 
power, government appointed a commission for this purpose in 1956. However, the commission could not present conclusive evidence of the feasibility of such a programme. ${ }^{11}$

The 1960s was characterised by a resurgence of Afrikaner nationalism under the premiership of Hendrik Verwoerd. Not only did he unilaterally declare South Africa a republic, and thus no longer a British subject, Verwoerd was also instrumental in stimulating ethno-nationalist science projects to showcase Afrikaner self-sufficiency and competence. In 1965, Verwoerd inaugurated South Africa's first nuclear reactor, the South African Fundamental Atomic Research Installation (SAFARI-1). Further nuclear-related developments followed in May 1968 when the government published a report on the possible introduction of nuclear power in the country. ${ }^{12}$ The report resulted from a request by the minister of mines and planning, J.F.W. Haak, in June 1965 to investigate the feasibility of nuclear power in South Africa. ${ }^{13}$ Although the 1968 report focused on the possible use of nuclear energy for power generation to stimulate industrial development, it also paved the way for South Africa's nuclear weapons programme and the nuclear devices the country eventually produced.

Based on further studies conducted by the South African Electricity Supply Commission (Escom, or its more commonly used Afrikaans acronym, Eskom), the Atomic Energy Board (AEB), the state-run Council for Scientific and Industrial Research (CSIR), various government departments and South African universities, in 1974 the South African government decided to construct a commercial-size light water reactor for electricity generation. In 1974 and 1975, the South African government informed the International Atomic Energy Agency (IAEA) of its intention to construct a nuclear power station. It also informed the IAEA that preliminary studies had been conducted and that an international tender process was underway to select the construction firm. ${ }^{14}$ A French consortium, Framatome Alsthom Spie Batignolles Framateg (hereafter Framatome) won the contract, which was duly signed on 5 and 6 August 1976 in Johannesburg and Paris, respectively. ${ }^{15}$

\footnotetext{
${ }^{11}$ A. Newby-Fraser, Kettingreaksie. Twintig Jaar van Kernavorsing en Ontwikkeling in SuidAfrika (Raad op Atoomkrag, Pretoria, 1979), p 127.

12 Atomic Energy Board (hereafter AEB), Report on the Investigation into the Possible Introduction of Nuclear Power in the Republic of South Africa (AEB, Pelindaba, 1968).

${ }^{13} \mathrm{AEB}$, Report on the Investigation into the Possible Introduction of Nuclear Power.

${ }^{14}$ GC(XVIII)/INF/149/Add.7, International Atomic Energy Agency (hereafter IAEA) General Conference, Eighteenth Regular Session: Advances in the Application of Nuclear Energy for Peaceful Purposes. Information transmitted by South Africa, 16 September 1974, at https://www.iaea.org/About/Policy/GC/GC18/GC18InfDocuments/English/gc18inf-149add7 en.pdf (accessed 29 July 2015). See also GC(XIX)/INF/156, IAEA General Conference, Nineteenth Regular Session: Advances in the Application of Nuclear Energy for Peaceful Purposes. Information received from governments, 16 September 1975, at https://www.iaea.org/About/Policy/GC/GC19/GC19InfDocuments/English/gc19inf156 en.pdf (accessed 29 July 2015).

${ }^{15}$ Newby-Fraser, Kettingreaksie. Twintig Jaar van Kernavorsing en Ontwikkeling in Suid-Afrika, p 131.
} 
International reaction to the awarding of the contract was concerned whether this development might contribute to South Africa's nuclear weapons programme, which at the time was suspected, but not confirmed. Speaking in the French National Assembly in June 1976, the French foreign minister stated that France would be delivering two industrial power reactors which would "have no real effect on the production of nuclear arms". ${ }^{16}$ Also in 1976, the United States (US) unilaterally refused to make any further exports of fuel elements for the US-supplied SAFARI-I, protesting against South Africa's alleged nuclear weapon programme and racial policies. This was detrimental to the previously close nuclear relationship between the two countries which originated in 1957 with a bilateral agreement on the civilian uses of nuclear energy. ${ }^{17}$ Growing international fears were eased somewhat in 1977, when France, the IAEA and South Africa signed an agreement for the application of certain safeguards in South Africa. ${ }^{18}$ This regulated the construction and operation of the Koeberg nuclear facility. Moreover, South Africa undertook not use specified items for the manufacture of nuclear weapons. By early 1978, more than 100 South African technicians were undergoing training in France in preparation for the operation of Koeberg's two reactors. ${ }^{19}$

Despite some progress in the construction of Koeberg, the project was dealt another blow in 1978 when the US Congress enacted its Nuclear Non-Proliferation Act (NNPA). The NNPA had a direct bearing on South Africa because it prevented the transfer of nuclear technology to states that were not party to the treaty on the NonProliferation of Nuclear Weapons (NPT) which came into force in 1970. South Africa refused to sign the NPT and was thus affected retroactively by the NNPA with respect to all the previous agreements and contracts between the US and South African governments. This resulted in the refusal by the US to issue export permits to South Africa "for the shipment to France of its own uranium already enriched" by the US Department of Energy (USDOE) for Koeberg. This development also negated a contract signed in 1974 between Framatome and Eskom. Moreover, the USDOE held Eskom fully accountable for the enrichment operations already completed by the USDOE. ${ }^{20}$

The impasse over Koeberg's fuel was resolved when the US president, Ronald Reagan took office in 1981. The Reagan administration agreed that France could manufacture and deliver fuel for Koeberg, but with a caveat, "should ESKOM succeed in providing enriched uranium to France from a source outside the USA". This issue

\footnotetext{
${ }^{16}$ Wilson Centre Digital Archive, Document number 114149, J. Sauvagnargues, Reply by the French Minister of Foreign Affairs to a question in the National Assembly, 2 June 1976, at http://digitalarchive.wilsoncenter.org/document/114149 (accessed 29 July 2015).

${ }_{17}$ Stumpf, "Birth and Death of the South African Nuclear Weapons Programme".

18 "France-International Atomic Energy Agency-South Africa: Agreement for the Application of Safeguards in South Africa, 5 January 1977", International Legal Materials, 16, 2, 1977, pp 276-284.

${ }^{19}$ Barber and Barratt, South Africa's Foreign Policy, p 240.

${ }^{20}$ Stumpf, "Birth and Death of the South African Nuclear Weapons Programme".
} 
was only resolved by $1984 .{ }^{21}$ Framatome, however, announced in November 1981 that it would export almost 100 tonnes of low-enriched uranium to start up Koeberg. With this move, the US lost some of its bargaining power over South Africa. Furthermore, Eskom and Framatome were able to acquire additional fuel from Switzerland and Belgium. ${ }^{22}$ A major US volte face followed in 1982, when the Reagan administration approved the export of dual-use nuclear related material to South Africa. Further US exports amounting to US $\$ 50$ million of technical and maintenance services for Koeberg followed in $1983 .{ }^{23}$

As international suspicion of South Africa's nuclear weapons programme increased, the construction of Koeberg and the country's suspected nuclear weapons programme also became a focus area of the liberation movement's actions against the South African government. In 1979, Abdul Minty, one of the ANC's staunchest antinuclear South African activists and one of the founder members of the Anti-Apartheid Movement (AAM) in the UK, established the World Campaign against Military and Nuclear Collaboration with South Africa. ${ }^{24}$ It was also suspected at the time that Koeberg may have been related to the government's nuclear weapons programme by producing weapons-grade plutonium. Decades later, Abdul Minty, admitted that the ANC had "always believed that Koeberg and other civilian programmes [were] actually ... the base and the cover for a nuclear weapons programme". ${ }^{25}$

By 1980, the impact of South Africa's regional policy of destabilisation of proANC states had resulted in major developments in the region, and was widely condemned. A study by the UN secretary general released in 1980 concluded that the NP's policy of apartheid posed the "greatest threat" to peace in southern Africa. ${ }^{26}$ The report concluded by stating that:

the greatest threat to peace in the region stems from a racist regime's denial of basic rights to the overwhelming majority of the population and its willingness to use strong repressive means, both internally and externally, to preserve its interests and privileges. ${ }^{27}$

${ }^{21}$ Stumpf, "Birth and Death of the South African Nuclear Weapons Programme".

22 A. van Wyk, "Sunset over Atomic Apartheid: United States-South African Nuclear Relations, 1981-83", Cold War History, 10, 1, 2010, p 56.

23 Van Wyk, "Sunset over Atomic Apartheid", pp 56-57.

${ }^{24}$ E. Reddy, Anti-Apartheid Movement and the United Nations: Statements, Papers and Letters of Abdul S. Minty, Honorary Secretary of the British Anti-Apartheid Movement and Director of the World Campaign against Military and Nuclear Collaboration with South Africa (Sanchar Publishing House, New Delhi, 1994).

${ }^{25}$ A. Minty, "The Nuclear Debate", Keynote address, to Environmental Monitoring Group (hereafter EMG) and the Western Cape ANC Science and Technology Group, Proceedings of a Conference on Nuclear Policy for a Democratic South Africa, Cape Town, 11 to 13 February 1994 (EMG, Cape Town, 1994), p 12.

${ }^{26}$ United Nations (hereafter UN), A45/571, "South Africa's Nuclear-tipped Ballistic Missile Capability. A Report by the Secretary General", 1991, at http://www.un.org/ disarmament/HomePage/ODAPublications/DisarmamentStudySeries/PDF/SS-23.pdf (accessed 29 July 2015).

27 UN, “South Africa's Nuclear-tipped Ballistic Missile Capability”. 
The report also cited possible reasons for South Africa's nuclear weapons programme, namely that it was envisaged as:

... a deterrent or intimidatory instrument against neighbours; as an assertion of defiance and desperation (presumably a last resort device); and as a means of intimidating black South Africans and lessening the risk of internal unrest while boosting the morale of the beleaguered whites.

It went on to suggest that South Africa, "rather than deploy or openly test nuclear weapons ... might seek to follow and exploit a policy of ambiguity or latent proliferation". 28

Thus, with an increased sense of insecurity, the NP government escalated its security in respect of its Border War, its cross-border attacks on ANC bases, and internal crackdowns of protest. This soon resulted in a reciprocal escalation from the liberation movements.

\section{"A new level in the armed conflict"}

Umkhonto we Sizwe (MK) was established on 16 December 1961, a date which coincided with one of Afrikaner nationalists' most revered dates, because 16 December, the Day of the Covenant, commemorated the Boer victory over the Zulus in 1838. From 1976 until 1978, MK members were trained by Cuban and Soviet instructors in Angola (more especially after Angola gained its independence from Portugal), and thereafter by ANC and MK instructors. MK operatives also attended specialised courses in Algeria, Bulgaria, Cuba, the German Democratic Republic (GDR), Hungary, the Soviet Union, and the former Yugoslavia. ${ }^{29}$ It was, however, the ANC's relations with the Soviet Union, the ANC's major arms supplier that was by far the most productive. ${ }^{30}$

Following the release of the ANC's Green Book mentioned earlier, the ANC's deployment of its armed wing gained new momentum. It was decided to resume MK's operations in South Africa. These so-called G5 Operations were orchestrated by Siphiwe Nyanda from 1978 onwards. A related development was the establishment of the 19-member MK Special Operations Unit (SOU), which was also called the Solomon Mahlangu Unit, in 1979.31 Established by Oliver Tambo, the SOU Command included

\footnotetext{
${ }^{28}$ UN, "South Africa's Nuclear-tipped Ballistic Missile Capability".

${ }^{29}$ T. Motumi, "Umkhonto we Sizwe: Structure, Training and Force Levels (1984 to 1994)", African Defence Review, 18, 1994, available online at http://www.iss.co.za/pubs/asr/ADR18/Motumi.html (accessed 25 March 2013).

${ }^{30}$ I. Filatova and A. Davidson, The Hidden Thread. Russia and South Africa in the Soviet Era (Jonathan Ball Publishers, Cape Town, 2013), pp 298-339.

31 The TRC refers to both the Solomon Mhlongo Unit and the Solomon Mahlangu Unit. See, for example, TRC, Amnesty Committee Decision AC/2001/003, 16 January 2000, at http://www.justice.gov.za/trc/decisions/2001/ac21003.htm/ (accessed 25 March 2013);
} 
Joe Slovo, Montso Mokgabudi and Aboobaker Ismail. With its own command structure, the SOU reported directly to the president of the ANC. Details of operations was highly classified and only the SOU Command had full knowledge of them. According to Ismail, the intention of the SOU was to attack "strategic targets of an economic and military designed nature to have maximum impact". ${ }^{32} \mathrm{~A}$ new MK military headquarters was established in Lusaka, Zambia, and Slovo was appointed as the chief of staff of MK. In addition to these developments, changes in reporting were also instituted such as Special Operations Command reporting to military headquarters in Lusaka through Joe Slovo and no longer directly to Tambo, the president of the ANC. Moreover, the ANC established additional facilities in Angola, Mozambique and Tanzania. ${ }^{33}$

With approximately 60 members, the purpose of the SOU was to execute high impact attacks on economic and military targets in South Africa through small units consisting of 2 to $6 \mathrm{MK}$ members. The establishment of the SOU resulted in an increase in sabotage incidents. It is estimated that between 150 and 160 attacks took place between 1976 and $1982 .{ }^{34}$ These high profile targets were mentioned earlier and also included fuel and military targets such as the headquarters of the South African Air Force (SAAF) in 1983.35 For the ANC these were "spectacular operations that would hit the economy hard". ${ }^{36}$ Moreover, these attacks were regarded as evidence of a "new level in the armed conflict" between the South African government, and the ANC and its allies. ${ }^{37}$

In 1982, the MK SOU established the Dolphin Unit in Durban as a further internal unit to operate in South Africa. The members of the Dolphin Unit included Mohammed Iqbal Shaik and Mohammed Abdulhai Ismail. Both were recruited and trained by Aboobaker Ismail, the Dolphin Unit general commander, who had the freedom to identify targets and recruit members..$^{38}$

With its new structures and chains of command, MK resumed its activities in South Africa. The sharp end of MK was, however, to receive an unexpected gift from an unexpected source: the South African national swordsman champion.

\footnotetext{
TRC, Amnesty Committee Application in Terms of Section 18 of the Promotion of National Unity and Reconciliation Act (Act No. 34 of 1995). See also TRC, Decision AC/2001/2422001, at http://www.justice.gov.za/trc/decisions\%5C2001/ac21242.htm (accessed 28 May 2015).

32 A. Ismail, "The ANC's Special Operations Unit", The Thinker, 58, 2013, p 33.

33 Ismail, "The ANC's Special Operations Unit".

${ }^{34}$ ANC, The ANC's Second Submission to the TRC; T. Lodge, "The African National Congress in South Africa, 1976-1983: Guerrilla War and Armed Propaganda", Journal of Contemporary African Studies, 3, 1, 1983/4, pp 153-154.

35 TRC, Amnesty Committee Decision AC/2001/003.

${ }^{36}$ ANC, The ANC's Second Submission to the TRC.

${ }^{37}$ Tambo, Opening Speech at the First Conference of the ANC, 5 July 1983.

38 TRC, Amnesty Committee Decision AC/2001/003.
} 


\section{Wilkinson's sword}

Rodney Wilkinson, a former South African national fencing champion dropped out of the University of Cape Town without completing his studies in Building Science and Politics. Despite his anti-nuclear sentiments, Wilkinson joined a commune close to where Koeberg was under construction. He soon found himself employed as a draftsman for one of the Koeberg contractors. By the time his girlfriend, speech therapist Heather Gray, convinced him to steal a set of Koeberg's building plans he had already been working at the site for 18 months.

Rodney Wilkinson was a very fortunate man - again. Without any background check whatsoever, Wilkinson was employed at the plant which was still under construction in $1978 .{ }^{39} \mathrm{Had}$ a background check been done on him at the time, Wilkinson's anti-nuclear sentiments and his history of military desertion from the SADF would have come to light. While serving as a corporal in the SADF during South Africa's invasion of Angola in the mid-1970s, along with 12 fellow servicemen, Wilkinson deserted, wrecking an armoured truck and ending up in hospital. Despite investigations into the incident, Wilkinson was never prosecuted by the SADF. ${ }^{40}$

Once Wilkinson had stolen the plans, the couple travelled to newlyindependent Zimbabwe to make contact with the ANC. Meeting with Mac Maharaj, they explained the purpose of the meeting, namely to hand the plans over to the ANC for possible use in an attack. ${ }^{41}$ Suspicious of infiltration by the South African security establishment, the ANC put Wilkinson through a vetting process. Then Maharaj presented the plans to the SOU commander, Joe Slovo. The stolen plans were also presented to Soviet and unspecified Western nuclear scientists who authenticated it. ${ }^{42}$ Once the ANC had vetted Wilkinson and Gray's credentials and the plans, Wilkinson was asked - and he agreed - to carry out an attack on Koeberg. (The operation was code-named Operation Mac, after Mac Maharaj). Upon his return to South Africa, Wilkinson resumed his employment at the Koeberg construction site. ${ }^{43}$

The ANC assigned Ismail, the Dolphin Unit general commander, to lead Operation Mac and he duly met up with Wilkinson in Swaziland to plan the attack on Koeberg. ${ }^{44}$ Ismail explains:

\footnotetext{
${ }^{39}$ South African History Online (hereafter SAHO), "The Freedom Struggle in Cape Town", available at http://www.sahistory.org.za/cape-town/conflict-among-civicorganisations?page $=2$, (accessed 25 March 2013).

${ }^{40}$ D. Beresford, Truth is a Strange Fruit: A Personal Journey through the Apartheid War (Jacana Media, Auckland Park, 2010), p 106.

${ }^{41} \mathrm{~A}$. Ismail, Interviewed by Padraig 0’ Malley, 21 February 2003, 0’ Malley Archives, at http://www.nelsonmandela.org/omalley/index.php/site/q/03lv03445/04lv03833/05lv038 91/06lv03900.htm, (accessed 15 March 2013).

${ }^{42}$ Beresford, Truth is a Strange Fruit, p 103.

${ }^{43}$ SAHO, "The Freedom Struggle in Cape Town".

${ }^{44}$ Ismail, Interviewed by Padraig 0’ Malley, 21 February 2003.
} 


\begin{abstract}
My job in terms of dealing with that operation was to guide and direct Rodney in terms of what he should be able to take out which was to get him to describe to me, read the plans and things and then have discussions with him and say $\mathrm{OK}$, let's see what kind of access we could get, which is what we were able to do quite well. In fact Rodney and I worked up to a very close working relationship there. He was able to tell me what he was doing and I would say to him, now try to do this, do that, do that, etc., and I would guide him through the process. Being on the inside of the plant he was able to get the equipment in and then carry out the operation. $45^{45}$
\end{abstract}

In preparation for the attack, Wilkinson visited Swaziland once a month under the pretence of a "dirty weekend" outside the borders of conservative South Africa. ${ }^{46}$ Three possible targets were identified, namely the two reactor heads (the heart of the plant); a section of the containment building; and a concentration of electric cables under the main control room. ${ }^{47}$ The choice of the 110 tonnes of steel reactor head was deliberate because it was to be used to control the nuclear reaction and maximise the propaganda effect. ${ }^{48}$

In the Karoo, an isolated part of the country, members of MK left various dead letter boxes containing four limpet mines for Wilkinson and his girlfriend to collect and take to Cape Town. The date for the attack was set for a day very symbolic for both black and white South Africans: 16 December (1982). For whites it was the Day of the Covenant commemorating the Battle of Blood River in 1838 which saw the Voortrekkers triumphing over Dingaan's Zulu “impis" (warriors). Blacks commemorated 16 December as MK Day, the day of the establishment of the ANC's armed wing. 49

Despite meticulous planning, a series of events occurred almost derailing the operation. Several security-related incidents, raising concerns, occurred at Koeberg during the course of 1982. In May 1982, four men entered the security zone of the facility and attempted to break into a safe. A second incident occurred in July 1982 when a fire destroyed some electrical equipment. Prematurely, the ANC accepted responsibility for the fire because Operation Mac was already underway. However, this claim was dismissed by the management of the state-owned power facility. A third incident took place in August 1982 when two men entered the security zone and came within a few meters of the nuclear reactor before they were discovered and arrested..$^{50}$ While the ANC's activity in the Western Cape did indeed increase significantly in the early 1980s it remains questionable whether any of these security breaches were in fact related to ANC actions.

\footnotetext{
45 Ismail, Interviewed by Padraig O’ Malley, 21 February 2003.

46 Beresford, Truth is a Strange Fruit, p 103.

${ }^{47}$ SAHO, "The Freedom Struggle in Cape Town".

${ }^{48}$ D. Beresford, "The Swordsman and the Bomb", Sunday Times, 29 August 2010, p 2.

${ }^{49}$ Beresford, Truth is a Strange Fruit, p 104.

50 “Koeberg Aanval sy Werk: ANC", Die Burger, 20 December 1982, p 1.
} 
In response to these breaches, security at Koeberg was tightened. However, once Wilkinson collected the dead letter box in the Karoo and returned to Cape Town, he smuggled the mines through the perimeter of the security fence at Koeberg, hiding them in his desk drawer before smuggling them into the main building. Wilkinson did not manage to install the mines on the targeted date of 16 December 1982, but only finished planting the bombs on 17 December. The fuses were set for a 24-hour delay to explode on 18 December when the plant would be deserted. ${ }^{51}$

Four explosions occurred in an approximately 24-hour period: 03:23; 08:40; 11:24 (on 18 December 1982), and 02:53 (on 19 December 1982).52 Wilkinson had thus successfully penetrated Koeberg's security to plant four limpet mines on the two reactor heads at the power station, as well as at strategic points under the plant's control rooms. ${ }^{53}$ By then, Wilkinson had skipped the country into Swaziland via Johannesburg. From Swaziland he went to Mozambique where he joined his girlfriend and met Oliver Tambo, "the two men crying [sic] in each other arms at their triumph". ${ }^{54}$ After that, the young couple proceeded to Britain where they lived in exile.

On 19 December 1982 the ANC accepted responsibility for the Koeberg explosions. In a statement issued in Dar es Salaam, the ANC stated that the attack was meant as a "salute to all our fallen heroes and imprisoned comrades, including those buried in Maseru", which referred to the 42 ANC members killed there in a South African Defence Force (SADF) raid on 8 December $1982 .{ }^{55}$ A major propaganda victory for the ANC, the Koeberg attack raised urgent questions in white South Africa and abroad.

\section{Reaction to the Koeberg bombing}

Nationally, questions were raised on why and how it was possible that an ANC attack could occur at a nuclear facility. The cabinet met for an urgent meeting with the State Security Council in Cape Town to discuss the explosions. ${ }^{56}$ The minister of Minerals and Energy, Piet du Plessis explained that because Koeberg was still under construction it was very difficult to provide watertight security because there were approximately 5000 people working on the construction site. As many as 450 of these were currently busy in the controlled and classified containment building of the reactor unit 1; while in reactor unit 2 there were 4400 people working on the

\footnotetext{
${ }^{51}$ SAHO, "The Freedom Struggle in Cape Town".

52 “Koeberg Aanval sy Werk: ANC", Die Burger, 20 December 1982, p 1.

${ }^{53}$ D. Beresford, "How we Blew up Koeberg (... and Escaped on a Bicycle)", Mail \& Guardian, 15 December 1995, at http://mg.co.za/article/1995-12-15-how-we-blew-up-koeberg-andescaped-on-a-bicycle, (accessed 25 March 2013).

${ }^{54}$ Beresford, "How we Blew up Koeberg".

55 "Koeberg: SA's Ill-starred Nuclear Power Plant", Independent Online, 11 March 2006, at http://www.iol.co.za/news/politics/koeberg-sa-s-ill-starred-nuclear-power-plant-1.269096, (accessed 25 March 2013).

56 “Koeberg: Kabinet Dringend Byeen”, Die Vaderland, 21 December 1982, p 1.
} 
containment building, which was not classified as a controlled area. ${ }^{57}$ Du Plessis later announced that two of the four explosions had occurred in each of the two containment buildings and damaged electrical cables and other unspecified equipment. He went on to insist that there was "absolutely no danger of radio-active pollution". ${ }^{58}$ Although enriched uranium to be used to fuel the power station had been stored on the site for a number of months prior to the explosions, it was beyond the reach of the bombs. ${ }^{59}$ In the days following the explosions, the South African government confirmed that the bombings were being investigated. However, the opposition party in parliament called for an independent inquiry into the events. ${ }^{60}$

In addition to this, an editorial in the pro-government newspaper Die Transvaler observed: "Ons word maar so van tyd tot tyd deur die Sasols en Koebergs wakker geskud. Maar of ons wakker genoeg is om waaksaam te bly, is hoogs twyfelagtig".61 The newspaper also called for a revision of the Total National Security Plan to prevent similar terror attacks. ${ }^{62}$ The South African government responded, inter alia, with an escalation of its cross-border raids into neighbouring countries that were suspected of harbouring anti-government organisations. ${ }^{63}$

At the time, it was calculated that the bombing might delay the construction of the facility by as much as ten months and repairing the damage could well be ZAR450-500 million. ${ }^{64}$ However, in 1999 it was reported that the attack had delayed construction by 18 months and the cost of repairs was almost ZAR500 million. ${ }^{65}$ The identity of the bomber was only revealed in 1995. However, a former Eskom CEO, Ian McRae, stated that their investigations also showed a possible "link" to the German terror group, the Baader-Meinhof.66 This link could not be confirmed.

\footnotetext{
57. "Koeberg: Kabinet Dringend Byeen", Die Vaderland, 21 December 1982, p 1; "Ná Koeberg", Die Transvaler, 23 December 1982, p 6; "No Live Devices at Nuclear Plant", The Citizen, 10 February 1983, p 4.

58 "Damage to Koeberg not yet Assessed", The Citizen, 3 February 1983, p 4; "Koeberg May be Delayed", The Cape Times, 22 December 1982, p 1.

59 “Vertraging Kan Koeberg Miljoene Kos”, Die Burger, 23 December 1982, p 1.

60 'Koeberg May be Delayed', The Cape Times, 22 December 1982, p 1.

61 "From time to time we are awakened by incidents such as the Sasol and Koeberg attacks. However, it remains doubtful whether we are awake enough to remain vigilant". [Free translation from the original Afrikaans by the author.]; "Ná Koeberg", Die Transvaler, 23 December 1982, p 6.

62 "Ná Koeberg", Die Transvaler, 23 December 1982, p 6.

63 TRC, "The Former South African Government and its Security Forces", Volume 6, section 3, chapter 1, (TRC, 2003), pp 196, 220, available online at http://www.info.gov.za/otherdocs/2003/trc/3 1.pdf (accessed 6 May 2013).

64 "Vertraging Kan Koeberg Miljoene Kos", Die Burger, 23 December 1982, p 1.

65 “Oud-Bok en sy Vrou Kry Amnestie vir Aanval op Koeberg”, Beeld, 1 June 1999, p 4.

66 "Koeberg Marks 30 Years of Operations as SA Mulls New Nuclear Chapter", Engineering News, 4 April 2014, at http://www.polity.org.za/article/koeberg-marks-30-years-ofoperations-as-sa-mulls-new-nuclear-chapter-2014-04-04 (accessed 12 May 2014).
} 


\section{From Wilkinson's sword to Wilkinson's Bedford}

Wilkinson and Gray married in Woodbridge, Suffolk, after the Koeberg bombing. They continued working for the ANC, albeit in a very different way. In 1986, a South African called Mannie Brown, an exiled member of the South African Communist Party (SACP) and an ANC supporter resident in the UK, registered Africa Hinterland, a UKbased safari company, as a front for MK. ${ }^{67}$ Wilkinson, who knew Brown, suggested to him that the company's Bedford trucks be refitted and under the pretence of taking tourists from Europe and elsewhere on African safaris from Kenya to South Africa, be used to smuggle arms and ammunition for MK operations inside South Africa. Drivers were recruited from members of the UK and Dutch communist parties. For as little as about US\$150 500, travellers could enjoy a seven-week journey of $4500 \mathrm{~km}$ with Africa Hinterland. 68

Following the unbanning of the ANC and the onset of early political negotiations in South Africa, Africa Hinterland moved its operations to Johannesburg. From here, trips to smuggle arms were made to the Okavango Delta in Botswana, through to Bulawayo in Zimbabwe, before returning to Johannesburg. Over a period of five years, these trucks made 40 trips and transported 40 tonnes of arms, including AK-47s, ammunition, hand grenades, limpet mines and trinitrotolue (TNT), hidden in secret compartments, to the underground ANC caches in South Africa. Mannie Brown's son, David, has since produced a documentary, "The Secret Safari" (2001), which tells the story of Africa Hinterland. ${ }^{69}$

In 1993, Africa Hinterland closed shop because constitutional negotiations between the ANC and the National Party were at an advanced stage. In April 1994, the ANC won the first democratic elections in South Africa and established a Government of National Unity (GNU) together with its former foe, the NP. A year later, the Mail \& Guardian newspaper revealed the identity of the Koeberg bomber. ${ }^{70}$ After another two years, on 15 April 1996, the South African Truth and Reconciliation Commission (TRC) convened its first public meeting in an effort to uncover the country's past and promote reconciliation. However, it was only in 1999 that the TRC dealt with the Koeberg bombing.

\section{Accounting for the bombing}

Established in terms of The Promotion of National Unity and Reconciliation Act, No 34 of 1995, the TRC was to provide "for the investigation and the establishment of as complete a picture as possible of the nature, causes and extent of gross violations of

\footnotetext{
${ }^{67}$ Filatova and Davidson, The Hidden Thread, p 333.

68 "Tourism with a Twist", Time, 26 February 2001.

${ }^{69}$ City of Johannesburg, Liliesleaf Takes Trip back to 1963", 29 April 2008, at http://www.joburgarchive.co.za/index.php?option=com content\&task=view\&id=2420\&Item id=203, (accessed 13 May 2014).

${ }^{70}$ Beresford, "How we Blew up Koeberg".
} 
human rights" committed from 1 March 1960 onwards. Furthermore, the act made provisions for the granting of amnesty to a person who made a "full disclosure of all the relevant facts relating to acts associated with a political objective committed in the course of the conflicts" in the country. ${ }^{71}$

In its second submission to the TRC, the ANC explained the operations of MK since its establishment in 1961. It stated that the organisation "had no choice but to resort to armed struggle" after it was banned by the government in $1960 .{ }^{72}$ The ANC went on to disclose information on its chain of command, military training and the various phases of its liberation struggle. It also explained that its approach had changed by 1979 with tactics of increased guerrilla warfare and its so-called People's War when its Special Operations Unit (SOU) was established to orchestrate its operations in South Africa, which included the attack on Koeberg. ${ }^{73}$ The Wilkinsons successfully applied for amnesty for the bombing of Koeberg, disclosing that four limpet mines were planted and detonated at the facility. According to the TRC, the couple were members of MK, "attached" to the SOU, and "ordered to damage" Koeberg that was "a key source of power" for the NP government. ${ }^{74}$ However, they explained that Koeberg was not operational at the time of the bombing. According to the ANC:

Before the attack on Koeberg was approved, the ANC went to the trouble of employing reliable nuclear experts in Europe to determine without any shadow of doubt that there would be no danger to civilians as a result of the explosions. ${ }^{75}$

For the TRC, "The proposed attack was part of the overall strategy of attacking apartheid and its installations and consequently the previous government". ${ }^{76}$ Considering it a "successful act of sabotage", which "was clearly politically motivated", the TRC granted amnesty to the Wilkinsons on 31 May 199. ${ }^{77}$ Similarly, the commander of the Dolphin Unit, Aboobaker Ismail, was granted amnesty for his part in ANC operations, but he did not apply for amnesty for the Koeberg attack. ${ }^{78}$

Other individuals who were never prosecuted or subpoenaed to appear before the TRC, were those involved in the government's nuclear weapons programme. This was not the case with the NP government's chemical and biological weapons

\footnotetext{
${ }^{71}$ E. Doxtader and P. Salazar, Truth and Reconciliation in South Africa: the Fundamental Documents (David Philip, Cape Town, 2007), p 13.

72 ANC, The ANC's Second Submission to the TRC.

${ }^{73}$ ANC, The ANC's Second Submission to the TRC.

74 TRC, Koeberg Power Station Amnesty Decision, 31 May 1999.

75 Statement to the Truth and Reconciliation Commission, 1996, at http://www. nelsonmandela.org/omalley/index.php/site/q/03lv02167/04lv02264/05lv02303/06lv0230 4/07lv02305/08lv02312.htm (accessed 25 March 2013).

76 TRC, Koeberg Power Station Amnesty Decision, 31 May 1999.

77 TRC, Koeberg Power Station Amnesty decision, 31 May 1999.

78 TRC, Amnesty Committee Decision AC/2001/003.
} 
programme (the so-called Project Coast). ${ }^{79}$ It was also not the case in two other instances of pro-ANC and pro-Soviet Union nuclear espionage. Commander Dieter Gerhardt, the commander of the South African Naval Base at Simonstown, and his wife Ruth were arrested in 1983 and imprisoned for providing nuclear related documents to the Soviet Union. ${ }^{80}$ Similarly, Cape Town academic Renfrew Christie was imprisoned from 1979 until 1986 for providing information to the ANC on the NP government's nuclear weapons programme at Koeberg and inside information on the Sasol facility. ${ }^{81}$

\section{Conclusion}

The attack on Koeberg is an under-researched episode of South Africa's nuclear past. It is also an under-researched issue in the history of the liberation movements in South Africa. Therefore, this article attempted to make an initial contribution to uncovering this Cold War era event. It was one of the most spectacular acts of sabotage of one of Moscow's clients during the Cold War. For white South Africa, it confirmed its worst fears: the sharpness of the sword wielded by the liberation movements. Moreover, it confirmed the rationale for the country's nuclear deterrent strategy because the ANC's struggle escalated to new levels of violence against military, public and civilian targets. Furthermore, the Koeberg attack also confirmed the vulnerability of the country's nuclear programme following on the Gerhardt and Christie arrests.

The act also had symbolic value for the ANC, namely that the liberation movement was able to access high-security government facilities such as the nuclear power station and SADF headquarters. In addition, the attack had propaganda value because it indicated to the liberation movements and black South Africans that the ANC was making progress in its liberation struggle.

The attack also had an economic impact. Not only did it delay the completion of Koeberg until 1985, but it added a further financial burden on the shoulders of the NP government to restore the damage caused by the four explosions. It also meant that the country's energy security was compromised even further. South Africa's hydroelectric power supply from Cahora Basa in Mozambique at the time was clearly insecure and Pretoria was unsuccessful in its efforts to influence the pro-ANC government in Lesotho to construct hydroelectric schemes in the Maluti Mountains.

\footnotetext{
${ }^{79}$ H. Purkitt and S. Burgess, "South Africa's Biological and Chemical Weapons Programme: a Historical and International Perspective", Journal of Southern Africa Studies, 28, 2, 2002, pp 229-253.

${ }^{80}$ R. Trahair and R. Miller, Encyclopedia of Cold War Espionage, Spies, and Secret Operations (Enigma Books, New York, 2012), pp 113-114.

${ }^{81}$ SAHO, Renfrew Leslie Christie, undated biography, at http://sahistory.org.za (accessed 5 June 2014).
} 
The aftermath of the attack on Koeberg also revealed previously unknown aspects of South Africa's past such as the ingenuity of Wilkinson's Bedfords. Furthermore, it revealed the selective nature of post-apartheid South Africa's search for the truth and reconciliation. This is clear in Wilkinson's application for amnesty at the TRC, whereas no other application was made in respect of the country's nuclear weapons programme; yet it was made for Project Coast.

Nuclear terrorism remains a major weapon in the hand of the terrorist and/or his/her organisation, and a major nightmare for the state against whom it is aimed. Typically, the Cold War was concerned with superpower nuclear rivalry; thus symmetric warfare. However, the attack on Koeberg is one of the examples of asymmetric warfare during the Cold War. The bombing remains of huge political significance because it was carried out against Africa's only nuclear power plant. The attack also sent a clear message to the South African government and its allies, some of whom sidelined major United Nations embargoes and sanctions to assist the country in developing civilian nuclear energy and its nuclear weapons programme. 